\title{
MODAL POLITIK TJHAI CHUI MIE DALAM PEMILIHAN WALIKOTA SINGKAWANG TAHUN 2017
}

Ika Kartika ${ }^{1}$, Mudiyati Rahmatunnisa ${ }^{2}$ dan Neneng Yani Yuningsih ${ }^{3}$

${ }^{1}$ Sekretariat Jenderal Komisi Pemilihan Umum Republik Indonesia dan Mahasiswa Program

Pascasarjana Ilmu Politik Universitas Padjadjaran

${ }^{2}$ Departemen Ilmu Politik, Universitas Padjadjaran

${ }^{3}$ Departemen Ilmu Pemerintahan, Universitas Padjadjaran

E-mail: ika.fachrurrazi@gmail.com

\begin{abstract}
ABSTRAK.
Tulisan ini mengkaji modal politik yang dimiliki oleh Tjhai Chui Mie pada Pemilihan Walikota Singkawang tahun 2017. Pengendalian modal adalah salah satu masalah yang sering dihadapi oleh perempuan yang terlibat dalam politik. Secara luas terdapat anggapan bahwa wanita yang terjun ke politik berkorelasi dengan norma-norma tradisional. Tulisan ini menggunakan metode deskriptif kualitatif dengan menggunakan data yang dikumpulkan melalui wawancara mendalam dan studi dokumen selama periode April-Juni 2018. Hasil penelitian ini menunjukkan bahwa Tjhai Chui Mie mampu mengelola modal politiknya, yang saling terkait dengan modal sosial dan modal ekonomi. Dengan dukungan partai dan pengalaman politik sebagai legislator, Tjhai Chui Mie berhasil memanfaatkan jaringan sosial etnis dan agama yang kemudian berpengaruh dalam mendapatkan dana kampanyen. Dengan kemampuannya untuk mengelola modalitas tersebut, ia berhasil menjadi walikota perempuan keturunan Cina pertama di Indonesia.
\end{abstract}

Kata Kunci: Modal Politik; Kandidat Perempuan; Pemilu; Singkawang.

\section{POLITICAL CAPITAL OF TJHAI CHUI MIE IN 2017 SINGKAWANG MAYORAL ELECTION}

\begin{abstract}
This article examines the political capital held by Tjhai Chui Mie in the 2017 Singkawang Mayoral Election. Capital control is one of the problems that often faced by women that being involved in politics. It is widely recognized that women who plunge into politics correlated with a traditional setting. This study uses a descriptive qualitative method using data collected through in-depth interview and document study during the period AprilJune 2018. The results of this study show that Tjhai Chui Mie was able to manage her political capital, which interrelated to social capital and economic capital. With parties support and political experience as legislators, Tjhai Chui Mie succeeds in utilizing ethnic and religious social networks which later became influential in obtaining her campaign funds. By her ability to manage modalities, she achieved the first Chinese women mayor in the country.
\end{abstract}

Key words: Potlicial Capital; Woman Candidate; Election; Singkawang.

\section{PENDAHULUAN}

Demokrasi menjamin setiap warga negara baik laki-laki maupun perempuan memiliki hak untuk berpartisipasi dalam politik secara setara. Perempuan dalam berpolitik juga memiliki hak untuk memilih (right to vote) dan hak untuk dapat dipilih dalam pemilihan umum (right to stand for election). Perempuan seperti halnya laki-laki dapat menjadi pemenang dalam pemilihan umum.

Menurut Sarwono (2008: 23), pemilihan kepala daerah (Pilkada) pada hakikatnya merupakan pengakuan dan perwujudan dari hak-hak politik rakyat dan sekaligus merupakan pendelegasian hak-hak tersebut kepada wakilwakilnya untuk menjalankan pemerintahan. Pilkada juga merupakan proses rekrutmen politik, yaitu penyeleksian rakyat terhadap tokoh-tokoh yang mencalonkan diri sebagai kepala daerah, baik gubernur/wakil gubernur, bupati/wakil bupati ataupun walikota/wakil walikota. Aktor utama sistem pemilihan kepala daerah adalah rakyat, partai politik dan calon kepala daerah. Partai politik sebagai suatu organisasi sangat berperan dalam mencetak pemimpin yang berkualitas dan berwawasan luas. Pemimpin yang berkualitas ini tidak hanya 
berorientasi pada kepentingan partai politik yang diwakili. Ketika menjadi seorang pemimpin, ia otomatis menjadi pemimpin semua orang. Calon pemimpin yang mampu menarik simpati dan perhatian dari masyarakat luas merupakan asset yang sangat berharga bagi partai politik (Firmanzah, 2008: 70-71).

Sekarang ini, keikutsertaan perempuan dalam Pilkada mengisyaratkan akseptabilitas perempuan dalam jabatan publik. Dalam kajian tentang kandidasi perempuan di Jawa Timur dan Sulawesi Utara, Kemitraan menyebutkan bahwa akseptabilitas perempuan di jabatan publik setidaknya ditentukan oleh beberapa aspek. Pertama, perempuan setidaknya telah memiliki ambisi personal, sebuah tahapan yang penting untuk mendapatkan kekuasaan politik. Kedua, adanya peluang jabatan yang memungkinkan perempuan muncul sebagai kandidat politik. Dalam konteks ini perempuan setidaknya memiliki estimasi sumber-sumber politik sehingga bisa mengkampanyekan dirinya dalam proses kandidasi. Ketiga, dukungan organisasi politik yangmemungkinkanperempuandicalonkanoleh partai politik. Dukungan menjadi sangat penting untuk membantu perempuan memutuskan untuk mendapatkan jabatan (Kemitraan, 2011: 37).

Tulisan inimengkajifenomenakinerja politik perempuan yang terbilang prestisius, yakni Tjhai Chui Mie pada kontestasi Pemilihan Walikota Singkawang Tahun 2017. Dalam pemilu tersebut, Tjhai Chui Mie berhasil meraih suara terbanyak dan menjadi walikota perempuan pertama di kota itu. Pada Pemilihan Walikota Singkawang tahun 2017 terdapat 4 (empat) pasangan calon (paslon) yang dapat dilihat pada tabel di bawah ini.

Tabel 1. Daftar Pasangan Calon Pemilihan Walikota dan Wakil Walikota Singkawang Tahun 2017

\begin{tabular}{cll}
\hline No & \multicolumn{1}{c}{ Pasangan Calon } & \multicolumn{1}{c}{ Partai Pengusung } \\
\hline 1 & $\begin{array}{l}\text { Tjhai Nyit Kim, SH dan H. } \\
\text { Suriyadi. MS, S.Sos, M.Si }\end{array}$ & Golkar, PPP, PKPI (6 \\
2 & $\begin{array}{l}\text { Tjhai Chui Mie, SE dan } \\
\text { Drs. H. Irwan, M.Si }\end{array}$ & $\begin{array}{l}\text { PDIP, Nasdem, Hanura, } \\
\text { Demokrat (14 Kursi) }\end{array}$ \\
3 & $\begin{array}{l}\text { H. Abdul Mutalib, SE, ME } \\
\text { dan Muhammadin, SE }\end{array}$ & Gerindra, PKB, PAN, \\
4 & $\begin{array}{l}\text { Andi Syarif T.U.W, ST, MT, (10 Kursi) } \\
\text { M.Sidandr.H.Nurmansyah, }\end{array}$ & Perseorangan \\
& M.Kes
\end{tabular}

Sumber: pilkada2017.kpu.go.id, diakses pada 30 Maret 2018

Pemilihan Walikota Singkawang Tahun 2017 ini yang menarik adalah diantara pasangan calon tersebut terdapat dua figur perempuan yakni Tjhai Nyit Khim dan Tjhai Chui Mie. Keduanya sama- sama mengambil posisi calon walikota, sama-sama beretnis Tionghoa dan sama-sama bermarga Tjhai. Kedua calon walikota perempuan ini juga telah dikenal oleh masyarakat Singkawang. Tjhai Nyit Kim merupakan istri dari walikota petahana Awang Ishak, sedangkan Tjhai Chui Mie dikenal karena karirnya sebagai anggota DPRD Singkawang dari Partai Demokrasi Indonesia Perjuangan (PDIP). Calon walikota yang lain yaitu H. Abdul Mutalib, merupakan wakil walikota petahana. Sedangkan calon walikota dari perseorangan yaitu Andi Syarif juga dikenal oleh masyarakat Singkawang dengan karirnya sebagai pengusaha dan berkecimpung diberbagai organisasi baik di tingkat lokal sampai ke tingkat nasional. Jadi bisa dilihat bahwa semua calon walikota Singkawang ini merupakan tokoh yang sangat dikenal oleh masyarakat Singkawang.

Berdasarkan Keputusan Komisi Pemilihan Umum Singkawang Nomor 14/Kpts/KPUKota-019.435770/2017 tentang Penetapan Rekapitulasi Perolehan Penghitungan Suara dan Hasil Pemilihan Walikota dan Wakil Walikota Singkawang Tahun 2017, pasangan calon nomor 2 (dua) yaitu Tjhai Chui Mie dan H. Irwan ditetapkan sebagai pemenang dengan perolehan suara sebesar 38.486 suara atau sebesar 42,63\%, selanjutnya pasangan calon nomor 3 (tiga) yaitu H. Abdul Mutalib dan Muhammadin dengan perolehan suara sebanyak 24.241 suara atau sebesar 26,85\%, diikuti oleh pasangan calon nomor 4 (empat) yaitu Andi Syarif dan dr. H. Nurmansyah dengan perolehan suara sebanyak 15.321 suaraatausebesar $16,97 \%$ danyangterakhir adalah pasangan calon nomor 1 (satu) yaitu Tjhai Nyit Khim dan H. Suriyadi MS dengan perolehan suara sebanyak 12.239 suara atau sebesar $13,55 \%$. Artikel ini melihat bahwa keberhasilan Tjhai Chui Mie menjadi kandidat potensial terkait dengan faktor pengelolaan modalitas yang ia miliki, antara lain latar belakang kandidat, kemampuan mengefektifkan biaya politik, dan modal sosial. Pada umunya Pilkada di Indonesia menuntut para kandidat menguasai faktor ekonomi sehingga banyak yang berasal dari kalangan pengusaha, petahana atau birokrat. Pengusaha dianggap memiliki modal finansial yang kuat, sehingga dianggap mampu menanggung biaya kampanye yang mahal. Sementara petahana dan birokrat bisa memaksimalkan potensi struktur politik di bawahnya untuk mobilisasi sumber daya (satunama.org, 14 Februari 2017).

Kepemilikan modal menjadi penting di karenakan Pilkada bukan menjadi wilayah per- 
saingan antarpartai tetapi kandidatlah yang menjadi aktor kunci. Kandidat yang paling sukses umumnya adalah orang-orang lokal yang berkuasa dan kaya yang biasanya dari kalangan mantan birokrat atau pengusaha, tetapi kadang-kadang juga politisi partai yang memobilisasi sumber daya dan jaringan pribadi untuk bersaing. Partai politik sendiri sering memilih untuk mencalonkan kandidat dari luar jajaran mereka sendiri, lebih memilih untuk menemukan kandidat yang memiliki sumber daya untuk membiayai kampanye mereka sendiri (seringkali membayar partai untuk nominasi) dan yang juga memiliki popularitas dan elektabilitas yang cukup untuk mendapatkan peluang menang. Daripada hanya mengandalkan mesin partai untuk terpilih, sebagian besar kandidat menggunakan koleksi jaringan formal dan informal untuk mengorganisasikan kampanye mereka; ini mungkin termasuk jaringan birokrasi, kelompok agama, asosiasi etnis, jaringan bisnis dan sejenisnya, serta tim sukses di mana-mana atau "tim sukses" yang dibentuk kandidat. Selain itu, pemilih juga mengevaluasi kandidat atas dasar kinerja masa lalu dan tidak memilih incumbent yang mereka yakini tidak efektif (Aspinall \& Mas'udi, 2017: 419-420)

Dalam persaingan pemilu, modal politik menjadi faktor penting yang perlu dimiliki oleh kandidat dan partai politik. Modal politik adalah metafora yang digunakan dalam teori politik untuk mengkonseptualisasikan akumulasi sumber daya dan kekuatan yang dibangun melalui hubungan, kepercayaan, niat baik, dan pengaruh antara politisi atau partai dan pemangku kepentingan lainnya, seperti konstituen. Modal politik dapat dipahami sebagai jenis mata uang yang digunakan untuk memobilisasi pemilih, mencapai reformasi kebijakan, atau mencapai tujuan politik lainnya (Stomberg \& Szucs, 2007: 293). Sementara menurut Casey (2008) modal politik sebagai pendayagunaan keseluruhan jenis modal yang dimiliki oleh seorang pelaku politik atau sebuah lembaga politik untuk menghasilkan tindakan politik yang menguntungkan atau memperkuat posisi pelaku politik atau lembaga politik bersangkutan. Terdapat tujuh jenis modal utama yang menyediakan sumber daya politik yaitu modal lembaga, modal manusia, modal sosial, modal ekonomi, modal budaya, modal simbolik dan modal moral.

Jika mencermati proses pemilihan di dalam Pilkada secara langsung, Marijan (2006: 89) mengungkapkan secara metafora dapat digambarkan bahwa kontestasi ini ibarat balapan mobil.Kandidatberkemungkinanmemenangkan Pilkada manakala memiliki kombinasi di dalam kendaraan, yaitu adanya mobil yang baik, sopir yang piawai dan bensin yang memadai. Secara konseptual metafora itu terwujud dari tiga modal utama yang dimiliki kandidat yaitu modal politik (political capital), modal sosial (social capital) dan modal ekonomi (economical capital). Ketiga modal ini dapat mempengaruhi seorang kandidat dalam memperoleh dukungan dari masyarakat. Semakin besar akumulasi modal yang dimiliki oleh seorang kandidat maka semakin besar pula dukungan yang diperoleh. Berbagai modal tersebut masing-masing dapat berdiri sendiri tanpa adanya keterkaitan antara yang satu dengan yang lain, tetapi seringkali ketiganya berkaitan terlebih dalam penggunaan politik. Artinya, kandidat memiliki peluang besar terpilih manakala memiliki akumulasi lebih dari satu modal. Argumen yang terbangun adalah bahwa semakin besar seorang kandidat mampu mengelola tiga modal itu secara efektif, semakin berpeluang ia memaksimalkan potensi keterpilihannya.

Modal politik berarti adanya dukungan politik, baik dari rakyat maupun kekuatan politik yang dipandang sebagai representasi dari rakyat. Menurut Marijan (2007: 7), modal politik menunjukkan bahwa fungsi partai politik tidak terlepas sebagai pintu masuk bagi kandidat yang mengikuti kontestasi Pilkada. Modal sosial berkaitan dengan bangunan relasi dan kepercayaan (trust) yang dimiliki kandidat dengan masyarakat yang memilihnya. Termasuk didalamnya adalah sejauh mana kandidat mampu meyakinkan pemilih bahwa mereka memiliki kompetensi untuk memimpin daerahnya. Agar bisa meyakinkan pemilih, kandidat harus dikenal oleh masyarakat. Sedangkan modal ekonomi dipakai tidak hanya untukmembiayai pelaksanaan kampanye tetapi juga untuk membangun relasi dengan para pendukung, termasuk di dalamnya adalah modal untuk memobilisasi dukungan pada saat menjelang dan berlangsungnya kampanye. Untuk itulah modal ekonomi memiliki makna penting sebagai "penggerak" mesin politik yang dipakai. Tidak jarang, modal ini juga ada yang secara langsung dipakai untuk mempengaruhi pemilih. Misalnya, banyak ditemui kasus kandidat membagikan barang atau uang kepada pemilih.

Dalam memenangkan Pilkada, sejalan dengan yang diungkapkan Marijan di atas, Gou \& Liu $(2012$; 1342) juga menyatakan bahwa 
dalam setiap kampanye pemilu, masing-masing partai akan menggunakan sumber dayanya dalam mendukung kandidat yang mereka usung. Akan tetapi, hanya mendapatkan dukungan daru partai politik bagaimanapun biasanya tidak cukup. Pemilihan kandidat ditentukan oleh hubungan jaringannya sendiri oleh masyarakat. Dalam menyusun rencana strategis kampanye, modal sosial dapat dianggap sebagai modal politik mengingat kemampuannya untuk menye-diakan akses ke sumber daya jaringan dan harus dianggap sebagai salah satu aspek dalam penggalangan dana kampanye dan kontribusi kandidat yang dapat memungkinkan kandidat untuk meningkatkan jumlah dukungan suara pemilih.

Selanjutnya Firmanzah ( 2010: LV) juga menyatakan bahwa terdapat dua jenis modal politik dalam Pemilu. Pertama, modal kapital atau uang yang digunakan untuk membiayai kampanye. Politisi dan partai politik yang memiliki modal uang yang besar akan memiliki kekuasaan yang cukup besar untuk membangun program kampanye yang terintegrasi. Kedua, modal sosial di mana politisi maupun partai politik lebih mengedepankan akumulasi dari kredibilitas, popularitas, dan jaringan yang terdapat di masyarakat. Modal sosial ini dibangun melalui interaksi dinamis dengan masyarakat. Selanjutnya Haboddin (2017: 71) berpendapat bahwa modal politik dan modal sosial merupakan sumber kekuasaan yang sangat diperlukan bagi penguasa ataupun pemimpin politik. Penggabungan antara modal politik dan modal sosial bermanfaat bagi pemimpin politik karena berfungsi memperluas jaringan kekuasaan dalam tata kelola pemerintahan. Semakin besar seorang pemimpin politik memiliki modal politik dan modal sosial, kekuasaan semain kokoh dan tangguh. Baik modal politik maupun modal sosial perlu dibaca dalam satu rangkaian yang saling terkait yang dapat dilihat pada tabel berikut ini:

Beberapa peneliti telah mendiskusikan tentang modal kemenangan calon perempuan yang kemudian menjadi kepala daerah. Baharuddin\&Purwaningsih(2017)menganalisis modalitas calon bupati dalam tahun 2015 dengan studi kasus kemenangan Indah Putri Indriani sebagai Bupati di Kabupaten Luwu Utara Provinsi Sulawesi Selatan. Hasil penelitiannya mengungkapkan Indah Putri Indriani memiliki modal sosial, politik, budaya dan ekonomi sehingga berhasil terpilih menjadi Bupati Luwu Utara Periode 2015-2020 sekaligus menjadi bupati perempuan pertama di Sulawesi Selatan.
Diantara keempat modal tersebut, modalitas dominannya adalah modal politik. Hidayat (2016) meneliti kemenangan pasangan kandidat Vonnie Anneke Penambunan-Joppi Lengkong dalam Pemilukada Kabupaten Minahasa Utara tahun 2015. Hasil penelitiannya mengungkapkan kekuatan dari pasangan ini terdapat pada modal sosial dan modal budaya, yaitu Vonni Panambunan yang merupakan seorang mantan Bupati Minahasa Utara sudah cukup terkenal dan masih diingat oleh masyarakat ditunjang oleh Joppi Lengkong yang mempunyai banyak keluarga besar di Kabupaten Minahasa Utara. Tim suksesnya juga bekerja dengan baik dengan menggunakan modal yang tersedia dengan strategi pendekatan primordial seperti kunjungan ke rukun-rukun, organisasi-organisasi adat.

Tabel 2. Aktor, Modal Sosial dan Modal Politik

\begin{tabular}{|c|c|c|}
\hline Aktor & Modal Sosial & Modal Politik \\
\hline Penguasa & $\begin{array}{l}\text { 1. Memiliki } \\
\text { jaringan kuat } \\
\text { dengan lembaga } \\
\text { masyarakat dan } \\
\text { NGO; } \\
\text { 2. Ada } \\
\text { kepercayaan } \\
\text { yang terbangun } \\
\text { antara warga } \\
\text { negara dengan } \\
\text { pemimpin yang } \\
\text { bersifat timbal-- } \\
\text { balik } \\
\text { 3. Pemimpin } \\
\text { politik akan } \\
\text { melakukan } \\
\text { kinerja yang } \\
\text { baik sebagai } \\
\text { bentuk } \\
\text { pertanggung } \\
\text { jawaban kepada } \\
\text { masyarakat }\end{array}$ & $\begin{array}{l}\text { 1. Memiliki } \\
\text { dukungan } \\
\text { dengan partai } \\
\text { politik; } \\
\text { 2. Mendapat } \\
\text { dukungan dari } \\
\text { masyarakat/ } \\
\text { konstituen; } \\
\text { 3. Pemimpin } \\
\text { yang memiliki } \\
\text { kemampuan } \\
\text { komunikasi } \\
\text { politik di depan } \\
\text { publik; } \\
\text { 4. Memiliki } \\
\text { jaringan } \\
\text { sosial dengan } \\
\text { penguasa lain. }\end{array}$ \\
\hline
\end{tabular}

Sumber: Haboddin (2017: 72)

Tulisan ini mencoba mengkaji secara komprehensif tentang bagaimana Tjhai Chui Mie memaksimalkan potensinya sebagai kandidat dalam Pemilihan Walikota Singkawang tahun 2017 dari perspektif kepemilikan modal politik. Apalagi kepemilikan modal ini merupakan salah satu permasalahan yang sering dihadapi oleh perempuan untuk terlibat dalam politik. Padahal modal merupakan sumber daya politik yang digunakan untuk memenangkan, mendapatkan, mempertahankan, atau memperluas kekuasaan. Penulis menggunakan konsep dari Kacung Marijan untuk menganalisis karena modal politik, modal sosial dan modal ekonomi yang saling terkait satu sama lain. Modal sosial dan modal ekonomijugamerupakanbentukdarimodalpolitik itu sendiri dalam mencapai memaksimalkan 
potensi kandidat. Namun, meskipun pengelolaan modal politik menjadi fokus analisis, tulisan ini tidak bermaksud mengaitkannya dengan faktor kemenangan paslon Tjhai Chui Mie-H. Irwan karena sifat dari tulisan ini bukan kausalitas. Tulisan ini lebih menekankan pada bagaimana perjuangan politisi perempuan dari etnis Tionghoa dengan pengelolaan modalnya berhasil meraih keduduk-an sebagai kandidat paling potensial di suatu ajang pilkada.

\section{METODE}

Pendekatan penelitian yang digunakan adalah penelitian kualitatif deskriptif. Penelitian kualitatif merupakan penelitian yang bermaksud untuk memahami fenomena tentang apa yang dialami oleh subjek penelitian misalnya perilaku, persepsi, motivasi, tindakan, secara holistik, dan dengan cara deskripsi dalam bentuk kata-kata dan bahasa, pada suatu konteks khusus yang alamiah dan dengan memanfaatkan berbagai metode alamiah (Moleong, 2005: 6). Penelitian ini dilakukan dengan menggunakan metode pengumpulan data berupa studi dokumentasi dan wawancara mendalam. Penelitian dilakukan selama kurang lebih tiga bulan pada tahun $2018 \mathrm{di}$ Kota Singkawang. Pada wawancara mendalam, informan ditentukan dengan cara mendasarkan pada relevansi informan dengan data yang dibutuhkan. Hal ini melibatkan informan dari berbagai latar belakang seperti Walikota Singkawang terpilih, Wakil Ketua DPRD Singkawang, pengurus partai politik, Sekretaris dan Tim Kreatif Pemenangan, Sekretaris MABT Singkawang, akademisi, dan tokoh masyarakat. Sedangkan teknik dokumentasi yang digunakan antara lain profil kandidat, laporan dana kampanye dan harta kekayaan paslon, rekapitulasi perolehan suara dan artikel dari media massa. Setelah data dikumpulkan maka selanjutnya analisis data mengikuti tahapan analisis yang digagas Miles \& Huberman (1992: 16-20) yaitu yaitu reduksi data (data reduction), penyajian data (data display), dan penarikan kesimpulan atau verifikasi (conclutions). Hasil pengumpulan data ini kemudian dilakukan suatu pemilahan atau reduksi untuk kemudian penyajiannya dilakukan semaksimal mungkin.

\section{HASIL DAN PEMBAHASAN}

\section{Membangun Karier Politik Sebagai Modal Politik Tjhai Chui Mie}

Kandidat dalam Pilkada memerlukan dukungan politik yang diusung dari partai politik.
Partai politik merupakan salah satu pintu masuk utama bagi orang-orang yang ingin menduduki jabatan politik. Munculnya perempuan sebagai kepala daerah tentunya tidak dilepaskan dari peranan partai politik seperti halnya yang terjadi dengan Tjhai Chui Mie. Terjunnya Tjhai Chui Mie ke dalam politik dibangun sejak menjadi anggota DPRD Kota Singkawang selama tiga periode dimana karirnya dimulai pada saat dilantik menjadi anggota DPRD Kota Singkawang periode 2004-2009 melalui proses Pergantian Antar Waktu (PAW) pada tahun 2008 menggantikan Bong Wui Kong yang dipecat oleh Partai Perhimpunan Indonesia Baru (PIB). Pada periode 2009-2014, Tjhai Chui Mie terpilih menjadi Ketua DPRD Kota Singkawang setelah menempati urutan pertama perolehan suara karena mampu meraih suara tertinggi dari daerah pemilihannya yaitu Singkawang Barat sebesar 3.139 suara. Pada pemilu 2014, partai yang selama ini menaungi Tjhai Cui Mie yakni Partai PIB dinyatakan tidak lolos sebagai partai peserta pemilu 2014. Tjhai Cui Mie beralih ke Partai Demokrasi Indonesia Perjuangan (PDIP). Hasilnya adalah Tjhai Chui Mie tetap memperoleh suara tertinggi di Kota Singkawang melalui daerah pemilihan Singkawang Barat sebesar 3.103 suara yang mengantarkannya duduk kembali menjadi Anggota DPRD Singkawang periode 2014-2019.

Sebagai kader dari PDIP, Tjhai Chui Mie memang didukung penuh sejak awal untuk menjadi Calon Walikota Singkawang. Cornelis sebagai ketua DPD PDIP Provinsi Kalbar dari tahun 2014 bahkan sudah menyatakan pada tahun 2017 Tjhai Chui Mie harus maju menjadi Calon Walikota Singkawang karena Tjhai Chui Mie merupakan kader terbaik yang dimiliki PDIP dan bisa menang. Dari pernyataan Cornelis itulah, imbasnya adalah dipromosikan dari mulut ke mulut sebagai calon Walikota Singkawang padahal masih dua tahun menjelang Pilkada. (Wawancara TCM, 30 Mei 2018). Dukungan partai PDIP yang memang solid dari awal juga terlihat dalam hal kampanye. PDIP misalnya ada BKO dimana daerah yang tidak melaksanakan Pilkada tetapi kader PDIP di daerah tersebut turun membantu ke Singkawang sehingga dari atas sampai bawah, semua kader gotong royong baik dari PAC, DPC, DPD bahkan DPP (Wawancara dengan A, 3 Mei 2018).

Pengalaman politik juga merupakan faktor penting bagi kandidat perempuan. Karena salah satu pertimbangan partai politik dalam mengusung calon adalah melihat latar belakang kandidat. Seperti yang diungkapkan oleh Baer \& Hartmann (dalam O'Regan \& Stambough, 
2016: 2) kandidat perempuan sering mengalami pertanyaan yang lebih besar tentang kualifikasi mereka daripada kandidat laki-laki. Perempuan membutuhkan kesuksesan di tingkat yang lebih rendah untuk membangun kredibilitas pada jabatan yang lebih tinggi. Sementara laki-laki lebih mungkin dianggap berkualitas bahkan dengan pengalaman politik yang kurang. Dengan perjalanan karier politiknya, Tjhai Chui Mie dikenal sebagai politikus berpengalaman terutama di bidang legislatif. Kondisi ini tentunya berbeda dengan Tjhai Nyit Kim dimana dikenal masyarakat sebagai istri dari Walikota Singkawang 2012-2017 Awang Ishak. Tjhai Nyit Kim merupakan orang baru dalam politik dan dia juga pernah bertarung di Pemilu Legislatif tahun 2014 tetapi tidak terpilih (wawancara dengan ST, 18 Mei 2018).

Halserupasejalandenganyang diungkapkan oleh Yew-Foong (2017:5) bahwa Tjhai Nyit Kim dimana dikenal masyarakat sebagai istri dari Walikota Singkawang 2012-2017 Awang Ishak. Tjhai Nyit Kim dilihat oleh masyarakat sebagai upaya Awang Ishak untuk memperpanjang masa jabatan melalui politik kekerabatan dan sebagai pesaing untuk mengalihkan sebagian suara etnis Tionghoa dari Tjhai Chui Mie. Ternyata hal itu tidak membuahkan hasil, Tjhai Nyit Kim memiliki suara yang paling sedikit yaitu 13 , $55 \%$. Dengan pengalaman di legislatif tersebut menjadi modal politik Tjhai Chui Mie untuk melakukan pendekatan kepada masyarakat ataupun elit sehingga pada saat Pilkada Tjhai Chui Mie sudah kaya pengalaman politik. Kekuatan politik yang ada di Singkawang sudah ia jejaki dari jauh hari sebelum menjadi kandidat Walikota. Rekam jejak kandidat pada pemilihan sebelumnya (dalam hal ini Tjhai Chui Mie telah berhasil 3 periode menjadi anggota legislatif) menjadi bukti bahwa mereka yang berhasil dalam pemilhan sebelumnya lebih mungkin melakukannya dengan baik dalam pemilihan berikutnya.

\section{Modal Sosial: Jejaring Etnik dan Kelompok Keagamaan}

Modal sosial yang dimiliki Tjhai Chui Mie adalah pertama, interaksi sosial yang dilakukannya dengan masyarakat yang sudah terbangun sejak lama berupa rajin melakukan kegiatan sosial sehingga sosoknya dikenal oleh masyarakat. Tjhai Chui Mie rajin melakukan kegiatan sosial dari20(duapuluhtahun) yang lalu. Setiap ada bencana alam atau terdapat musibah,
Tjhai Chui Mie merupakan sosok yang selalu turun ke lapangan untuk membantu masyarakat tanpa membeda-bedakan etnisitas. (Wawancara dengan TM, 30 April 2018). Interaksi sosial ini membuat masyarakat mengenali sosok Tjhai Chui Mie sehingga dapat membangun suatu pola hubungan interaksi. Interaksi sosial sangat berguna untuk menelaah dan mempelajari banyak masalah di dalam masyarakat.

Kedua, jaringan sosial. Bentuk interaksi sosial yang semakin meluas akan menjadi jaringan sosial yang lebih memungkinkan semakin meluasnya lingkup kepercayaan dan lingkup hubungan timbal balik. Jaringan sosial ini terjadi berkat adanya keterkaitan antara individu dalam komunitas. Keterkaitan terwujud di dalam beragam tipe kelompok pada tingkat lokal maupun tingkat lebih tinggi. Jaringan hubungan sosial biasanya akan diwarnai oleh suatu tipologi khas sejalan dengan karakteristik dan orientasi kelompok. Jaringan sosial yang dimiliki Tjhai Chui Mie sejalan dengan ikatan kepercayaannya sebagai etnis Tionghoa yaitu menjadi Ketua Perkumpulan Hakka Indonesia (Perhakin) Kota Singkawang, Ketua Majelis Tao Indonesia (MTI) Kota Singkawang dan Dewan Kehormatan Yayasan Setia Negara, Serpong. Dengan bergabung dan mendapatkan jabatan pada organisasi tersebut, Tjhai Chui Mie juga membangun jaringan relasi yang dibuatnya dengan masyarakat atau pengusaha Singkawang etnis Tionghoa yang berada di Jakarta.

Ketua Perhakin Kota Singkawang juga secara tidak langsung membantu dalam kampanye Tjhai Chui Mie. Hakka mempunyai media masa sendiri seperti koran tetapi menggunakan bahasa mandarin. Cetak korannya itu tidak hanya di Singkawang, tetapi di juga Jakarta. Selain koran juga terdapat website Hakka Indonesia http://hakkaindonesia.or.id/ di mana di website tersebut juga terdapat berita terkini kegiatan yang dilakukan Tjhai Chui Mie. Karenanya, Tjhai Chui Mie bukan hanya dikenal sebagai tokoh Hakka di Singkawang, akan tetapi juga sebagai penggerak dan pemelihara kegiatankegiatan Hakka di Singkawang. Tjhai Chui Mie dapat dilihat berhasil memanfaatkan jaringan agama dan keetnisannya. Tjhai Chui Mie berasal dari etnis Tionghoa suku Hakka yang beragama Budha. Ini juga merupakan kekuatan Tjhai Chui Mie dalam meriah kemenangannya dikarenakan dukungan yang penuh dari etnis Tionghoa apalagi mayoritas etnis Tionghoa di Singkawang berasal dari Suku Hakka. Suku Hakka tersebar 
di seluruh kecamatan di Singkawang, tetapi terutama banyak di Singkawang Barat dan Singkawang Selatan di mana dua kecamatan inilah suara Tjhai Chui Mie menang telak (wawancara DSL, 4 Juni 2018).

Melihat demografi masyarakat Singkawang yang sebagian besar berasal dari etnis Tionghoa, maka Tjhai Chui Mie memanfaatkannya dalam berdiskusi dengan masyarakat Singkawang ketika kampanye menggunakan dua bahasa yaitu bahasa Indonesia dan bahasa Hakka/Khek. Karena di kalangan Tionghoa banyak orang tua tidak begitu mengerti bahasa Indonesia, serta untuk kalangan Tionghoa sendiri kadang ada terkesan rasa takut, bahkan untuk maju ke depan pada saat kampanye dialogis saja mereka takut. Jadi menggunakan bahasa Hakka merupakan salah satu cara memudahkan untuk mereka mengerti. (Wawancara dengan YYA, 4 Juni 2018). Jaringan kelompok agama dan keetnisan digunakan sebagai kekuatan untuk mendapatkan suara pemilih bukanlah sesuatu yang baru dalam Pemilihan Walikota Singkawang. Sejak Pemilihan Walikota 2007 yaitu ketika Hasan Karman terpilih, etnis Tionghoa tetap memilih sesama etnis Tionghoa. Walaupun ada Tjhai Nyit Kim yang sesama Tionghoa, hanya sedikit etnis Tionghoa memilihnya karena pengaruh agama. Menurut etnis Tionghoa, ketika ia keluar dari agamanya maka bukan lagi merupakan etnis Tionghoa. Tjhai Nyit Kim merupakan etnis Tionghoa beragama Islam, sehingga etnis Tionghoa yang bertarung hanya dianggap satu yaitu Tjhai Chui Mie. Oleh karena itu Tjhai Chui Mie didukung penuh oleh etnis Tionghoa di Singkawang (Wawancara dengan M, 23 Mei 2018).

Jaringan etnis tersebut juga dibangun dengan masyarakat atau pengusaha Singkawang yang berada di Jakarta. Yew-Foong (2017: 7) juga mengungkapkan Tjhai Nyit Kim dan Tjhai Chui Mie yang merupakan kandidat yang berasal dari etnis Tionghoa mengakui pengaruh elit Tionghoa Singkawang di Jakarta dan mereka juga "berkampanye" di Jakarta untuk mencari dukungan elit ini. Elit ini bukan hanya sumber pendanaan kampanye, lebih penting lagi mereka berpengaruh diantara kerabat di Singkawang dan dukungan mereka dapat membantu para kandidat untuk mendapatkan suara etnis Tionghoa. Dilihat dari laporan sumbangan kampanye dari kedua kandidat ini, Tjhai Chui Mie tampak lebih berhasil dalam mendapatkan dukungan dari elit Tionghoa Singkawang di Jakarta.
Hal ini juga diakui oleh Tjhai Chui Mie ketika ia memutuskan maju menjadi Calon WalikotaSingkawang, iamendapatkandukungan masyarakat di Singkawang bahkan pengusaha etnis Tionghoa di Jakarta dan daerah lainnya. Dukungan mereka sangat besar misalnya pada saat kampanye pun banyak dibantu misalnya atribut baju, gelang, dan lain-lain. (Wawancara dengan TCM, 30 Mei 2018)

Bukan hal yang baru bahwa kandidat memasukkan faktor etnisitas dan agama sebagai alat untuk memenangkan pertarungan Pilkada. Kandidat tentunya berupaya merekrut pasangannya dari kelompok etnis yang juga mayoritas pada daerah tersebut. Hal ini wajar saja, karena merupakan strategi untuk memenangkan pertarungan tersebut. Apa yang kita lihat dengan munculnya persoalan etnisitas dalam proses Pilkada merupakan suatu fenomena kecenderungan masyarakat kita dalam memilih calon pemimpin yang berasal dari kelompoknya. Hal ini juga berlaku ketika Tjhai Chui Mie memilih Irwan sebagai Wakil Walikota yang berasal dari melayu beragama muslim. Dengan perpaduan komposisi etnis agama tersebut (Tionghoa Budha dan Melayu Muslim) dimana merupakan mayoritas di Singkawang, mereka dianggap mewakili konstituen etnis-agama yang berbeda sehingga mampu menarik suara dari pemilih seluas mungkin.

Ketiga, kepercayaan masyarakat yang tinggi kepada Tjhai Chui Mie. Sebelum pendaftaran pencalonan walikota Singkawang, Lembaga Kajian Pemilu Indonesia (LKPI) mengadakan survei yang digelar 21-30 Juli 2016 untuk melihat sosok yang layak mempimpin Kota Singkawang. Survei yang menggunakan multistage random sampling dengan koresponden sebanyak 738 orang yang terpilih dari DPT (Daftar Pemilih Tetap) dari KPU Kota Singkawang. Hasilnya adalah 3 (tiga) nama yang tingkat popularitas atau dikenal oleh masyarakat Singkawang di atas $80 \%$ (delapan puluh persen) adalah Henoch Thomas (92,2\%), Tjhai Chui Mie $(90,7 \%)$ dan Abdul Muthalib (90,1\%). Ketiga nama tersebut dikenal oleh masyarakat didasari pada latar belakang tokoh tersebut (Tribunnews.com, 07 Agustus 2016).

Dari ketiga nama tokoh diatas, hanya Tjhai Chui Mie dan Abdul Muthalib yang pada akhirnya menjadi kandidat calon walikota. Namun, dengan tingkat popularitas yang tinggi, belum tentu kepercayaan masyarakat juga tinggi dalam konteks sebagai calon walikota Sing- 
kawang. Tetapi dengan dikenalnya sosok Tjhai Chui Mie yang rajin melakukan bakti sosial, aktif berorganisasi dan anggota DPRD Kota Singkawang, ternyata bukan hal yang sulit bagi Tjhai Chui Mie untuk mendapatkan kepercayaan dari masyarakat Singkawang sehingga berhasil memenangkan Pemilihan Walikota Singkawang tahun 2017. Terlebih lagi dilihat dari populasi penduduk Kota Singkawang yang cukup besar dari etnis Tionghoa.

Kepercayaan masyarakat Kota Singkawang tidak luntur kepada Tjhai Chui Mie meskipun ia diterpa masalah tersebarnya kalender palu arit. Sekitar 1000 (seribu) kalender impor yang berisikan penanggalan hari baik maupun hari buruk berdasarkan fengshui yang diyakini dan pada bagian tanggal 1 juli dari kalender tersebut terdapat lambang palu arit. Keberadaan gambar palu arit pada tanggal 1 juli merupakan hari besar bagi Republik Rakyat Tiongkok yaitu kembalinya Hongkong kepada Republik Rakyat Tiongkok (Pontianak.tribunnews.com, 30 Juni 2016). Karena masalah kalender ini, Tjhai Chui Mie selalu dikaitkan dengan PKI. Tetapi Tjhai Chui Mie dan tim kampanye berhasil mematahkan isu tersebut dengan selalu mengungkapkan NKRI harga mati. Kampanye dengan menggunakan tema nasionalisme, seperti Pancasila, Bhinneka Tunggal Ika, NKRI, memang menjadi salah satu tema yang digunakan oleh Etnis Tionghoa ketika turun berpolitik. Karena ketika etnis Tionghoa terlibat dalam politik selalu dikaitkan dengan ideologi komunis atau ideologi yang mempunyai manifestasi dengan ideologi negara cina sebagai ideologi negara leluhurnya. Karena itulah ketika Tjhai Chui Mie diserang oleh isu PKI karena penyebaran kalender palu arit, tema nasionalisme memang selalu diangkat ketika kampanye.

Di sini dapat disimpulkan bahwa melalui modal sosial, Tjhai Chui Mie tidak hanya dikenal oleh masyarakat akan tetapi diberi kepercayaan. Ketika dalam Pilkada posisi figure sangat penting dibandingkan partai politik, tentunya kepemilikan modal sosial sangat diperlukan. Tjhai Chui Mie menggunakan modal sosial melalui hubungannya dengan masyarakat, teman, kolega, elit politik dan elit non politik sehingga berhasil dipilih oleh partai pengusung untuk menjadi kandidat Walikota bahkan berhasil meyakinkan masyarakat untuk memimpin Kota Singkawang.

\section{Efektivitas Pengelolaan Modal Ekonomi}

Modal ekonomi salah satu menjadi ukuran penting yang harus dimiliki oleh kandidat untuk memenangkan kompetisi di dalam Pilkada diantaranya jumlah harta kekayaan pribadi dan dana sumbangan kampanye. Modal ekonomi tersebut berfungsi sebagai penggerak mesin politik yang dipakai terutama pada saat kampanye. Kampanye adalah kegiatan menawarkan visi, misi, dan program pasangan calon dan/atau informasi lainnya, yang bertujuan mengenalkan atau meyakinkan pemilih. Modal ekonomi yang dimiliki Tjhai Chui Mie berupa harta kekayaan dan dana kampanye. Modal ekonomi tersebut berfungsi sebagai penggerak mesin politik yang dipakai terutama pada saat kampanye. Menariknya, harta kekayaan yang dimiliki oleh Tjhai Chui Mie jika dibandingkan dengan kandidat lainnya terdapat perbedaan yang siginifikan. Harta kekayaan Tjhai Chui Mie tergolong paling sedikit dibandingkan kandidat calon walikota lainnya.

Tabel 3. Harta kekayaan Calon Walikota dan Wakil Walikota Singkawang Tahun 2017

\begin{tabular}{|c|c|c|}
\hline No & $\begin{array}{c}\text { Nama Pasangan } \\
\text { Calon }\end{array}$ & Harta Kekayaan \\
\hline 1 & $\begin{array}{l}\text { Tjhai Nyit Kim, SH } \\
\text { dan H. Suriyadi. MS, } \\
\text { S.Sos, M.Si }\end{array}$ & $\begin{array}{l}\text { Rp.1.027.154.000,- } \\
\text { Rp.1.614.145.865,- }\end{array}$ \\
\hline 2 & $\begin{array}{l}\text { Tjhai Chui Mie, SE } \\
\text { dan Drs. H. Irwan, } \\
\text { M.Si }\end{array}$ & $\begin{array}{l}\text { Rp.653.223.369,-- } \\
\text { Rp.295.145.865,- }\end{array}$ \\
\hline 3 & $\begin{array}{l}\text { H. Abdul Muthalib, } \\
\text { SE, ME. dan Muham- } \\
\text { madin, SE }\end{array}$ & $\begin{array}{l}\text { Rp.15.083.177.004,- } \\
\text { Rp.1.023.000.000,- }\end{array}$ \\
\hline 4 & $\begin{array}{l}\text { Andi Syarif, T.U.W., } \\
\text { ST, MT, M.Si (Han) } \\
\text { dan dr. H. Nurman- } \\
\text { syah, M.Kes }\end{array}$ & $\begin{array}{l}\text { Rp.12.419.642.890,- } \\
\text { Rp.179.318.000,- }\end{array}$ \\
\hline
\end{tabular}

Sumber: KPU Kota Singkawang, 2017.

Walaupun harta kekayaan Tjhai Chui Mie lebih sedikit dibanding kandidat lain, tetapi tidak menjadikannya satu-satunya modal yang dipunya untuk memenangkan Pemilihan Walikota Singkawang tahun 2017. Kepemilikan dana kampanye juga penting. Dana kampanye menjadi pokok pengaturan penting dalam UU No. 8 Tahun 2015 jo UU No. 10 Tahun 2016 tentang Pilkada. KPU juga telah mengeluarkan peraturan teknis mengenai dana kampanye dalam PKPU No. 8 tahun 2015 jo PKPU No. 13 Tahun 2016. Pengaturan dana kampanye ini bertujuan untuk menciptakan lapangan kontestasi yang setara antar kandidat, mencegah korupsi pilkada 
dan potensi korupsi akibat tingginya biaya pemenangan pilkada, mencegah pilkada menjadi kesempatan melakukan tindak pidana pencucian uang dan instrumen kepentingan bisnis, dan menjaga integritas pilkada dari segi pendanaan. (antikorupsi.org, 19 Desember 2017)

Dalam pelaksaaan Pilkada serentak 2017 berdasarkan PKPU no 12 Tahun 2016, kampanye oleh kandidat dapat dilakukan dalam bentuk pertemuan terbatas, tatap muka atau dialog, pemasangan bahan kampanye, pemasangan alat peraga kampanye, dan kegiatan lain yang tak melanggar aturan. KPU setempat dapat memfasilitasi kampanye yaitu debat publik, penyebaran bahan kampanye, pemasangan alat peraga kampanye, dan iklan di media massa. Selain itu juga diatur pembatasan dana kampanye. Adapun dana kampanye setiap paslon pada Pemilihan Walikota Singkawang Tahun 2017 dapat dilihat pada tabel 4.

Jumlah penerimaan dan pengeluaran dana kampanye pasangan Tjhai Chui Mie dan Irwan memang lebih sedikit dibanding paslon lain yang diusung oleh partai. Tetapi dilihat dari hasil audit Laporan Penerimaan dan Pengeluaran Dana Kampanye (LPPPDK), Tjhai Chui Mie berhasil memanfaatkan dana kampanye yang ada dengan baik yaitu digunakan sebagian besar untuk pertemuan tatap muka atau blusukan langsung ke rumah-rumah masyarakat. Lain hal dengan kandidat yang lain seperti Tjhai Nyit Kim ataupun Abdul Mutalib yang kampanyenya sebagian besar untuk pertemuan terbatas yang hanya sebatas orasi program. Tjhai Chui Mie memanfaatkan pertemuan tatap muka supaya langsung mengetahui permasalahan yang ada di masyarakat.

Tjhai Chui Mie juga berhasil memanfaatkan dana kampanye yang ada dengan menggabungkan strategi kampanye melalui offline dan online. Ketika Paslon lain hanya berkutat dengan strategi kampanye offline yaitu dialogis dengan masyarakat, Tjhai Chui Mie berhasil melakukan kampanye secara offline dan online untuk masuk ke pasar pemilih muda. Pasar pemilih muda ini tidak digarap oleh kandidat lain. Untuk strategi offline itu sendiri, proses kampanye dilakukan secara langsung kepada masyarakat. Tjhai Chui Mie membentuk relawan-relawan sesuai dengan segmentasi pemilih misalnya "Barisan Biak Chair" untuk pemilih muda dan "Relawan Semut Merah" yang menyasar pemilih perempuan dan pemilih golput. Dalam media sosial sebagai media kampanye terdapat pages Facebook "Tjhai Chui Mie", Instagram "Tjhai Chui Mie", dan You Tube "Tjhai Chui Mie", website http://tcm.ilmci. com bahkan Aplikasi Games "TCM4SKW" yang bisa didownload untuk android. Untuk kegiatan pemilih muda ada gerakan 10.000 selfie pendukung Tjhai Chui Mie untuk agen perubahan, membuat acara flashmob terbesar di Singkawang pada bulan Januari 2017, seminggu sekali mengadakan kegiatan "nogok plus plus" yang artinya nongkrong sambil diskusi positif misalnya bagaimana kedepannya Kota Singkawang. (Wawancara dengan TJ, 3 Mei 2018).

Keberhasilan Tjhai Chui Mie di Singkawang menjadi bukti bahwa tidak semua kandidat yang memiliki modal ekonomi yang besar maka otomatis menjadi pemenang. Dengan modal ekonomi yang dimilki Tjhai Chui Mie yang relatif sedikit dibanding kandidat lain, menjadikan modal ekonomi bukan satu-satunya modal yang untuk meraih kemenangan. Karena itulah akumulasi dari modal politik, modal sosial

Tabel 4. Laporan Penerimaan dan Pengeluaran Dana Kampanye Pemilihan Walikota Singkawang Tahun 2017

\begin{tabular}{clccc}
\hline No & \multicolumn{1}{c}{$\begin{array}{c}\text { Nama } \\
\text { Pasangan Calon }\end{array}$} & $\begin{array}{c}\text { Pembatasan } \\
\text { Pengeluaran Dana } \\
\text { Kampanye }\end{array}$ & $\begin{array}{c}\text { Jumlah } \\
\text { Penerimaan }\end{array}$ & $\begin{array}{c}\text { Jumlah } \\
\text { Pengeluaran }\end{array}$ \\
\hline 1 & $\begin{array}{l}\text { Tjhai Nyit Kim, SH } \\
\text { dan H. Suriyadi. MS, S.Sos, M.Si }\end{array}$ & Rp.2.900.157.650,- & Rp.1.2000.000.000,- & Rp.1.199.230.000,- \\
2 & $\begin{array}{l}\text { Tjhai Chui Mie, SE } \\
\text { dan Drs. H. Irwan, M.Si }\end{array}$ & Rp.2.900.157.650,- & Rp.931.900.000,- & Rp.892.543.700,- \\
3 & $\begin{array}{l}\text { H. Abdul Mutalib, SE, ME } \\
\text { dan Muhammadin, SE }\end{array}$ & Rp.2.900.157.650,- & Rp.1.007.527.333,- & Rp.1.006.314.000,- \\
4 & $\begin{array}{l}\text { Andi Syarif T.U.W, ST, MT, M.Si } \\
\text { (Han), dan dr. H. Nurmansyah, M.Kes }\end{array}$ & Rp.2.900.157.650,- & Rp.135.000.000,- & Rp.127.900.000,- \\
\hline
\end{tabular}


dan modal ekonomi harus dioptimalkan untuk diraih, tidak hanya sebatas mengandalkan salah satu modal saja.

\section{SIMPULAN}

Dalam kontestasi Pemilihan Walikota dan Wakil Walikota Singkawang tahun 2017, Tjhai Chui Mie berhasil membangun kekuatan personal sebagai kandidat dengan kemampuan mengelola modal politik. Beberapa aspek dalam modal tersebut antara lain kemampuan dia meniti karier politik di badan legislatif, sehingga memiliki popularitas dan elektabilitas yang cukup serta mendapatkan kepercayaan dari masyarakat. Dengan kekuatan itu ia berhasil memperoleh tiket dari partai politik untuk maju sebagai calon walikota Singkawang 2017. Selain itu, Tjhai Chui Mie menghubungkan modal politiknya dengan modal sosial yakni dengan memanfaatkan jejaring sosial berdasarkan ikatan etnik dan kelompok keagamaan. Sementara pada modal ekonomi, ia berhasil mengelola dana kampanye secara efektif atau tepat sasaran, sehingga meskipun tidak memiliki dana yang besar dibandingkan dengan kandidat lainnya, ia mampu meraih para pemilih terutama dari golongan pemilih muda. Karena itu, modal politik merupakan sumber daya yang mutlak dimiliki kandidat untuk mendapatkan dukungan dari partai politik sekaligus suara dari para pemilih. Bagi seorang perempuan, pencapaian Tjhai Chui Mie merupakan bukti bahwa ia mampu mengolah modal-modal tersebut menjadi potensi kemenangan sekaligus mematahkan hambatanhambatan tradisi terhadap kalangan perempuan dalam kehidupan politik demokratis.

\section{DAFTAR PUSTAKA}

Antikorupsi.org. (19 Desember 2017). "Dana Kampanye dan Masa Kritis Pilkada 2017'. Diakses pada 19 September 2018, https:/antikorupsi.org/sites/default/files/ files/Siaran\%20Pers/Rilis\%20dana\%20 kampanye $\% 20$ dan $\% 20$ masa $\% 20$ kritis\%20pilkada.pdf.

Aspinall, E. \& Mas'udi, W. (2017). The 2017 Pilkada (Local Electons) in Indonesia: Clientelism, Programmatic Politics and Social Networks. Contemporary Southeast Asia, 39 (3).

Baharuddin, T. \& Purwaningsih, T. (2017). Modalitas Calon Bupati Dalam Pilkada
Tahun 2015; Studi Kasus Indah Putri Indriani Sebagai Bupati Terpilih di Kabupaten Luwu Utara Provinsi Sulawesi Selatan. Journal of Governance and Public Policy, 4, 1, 205-237.

Casey, K.L. (2008). Defining Political Capital: A Reconsideration of Bourdieu's Interconvertibility Theory. Paper Presented at the llinois State University Conference for Student of Political Science. University of Missouri-St.Louis

Firmanzah. (2008). Mengelola Partai Politik: Komunikasi dan Positioning Ideologi Partai di Era Demokrasi. Jakarta: Yayasan Pustaka Obor Indonesia.

Firmanzah. (2010). Persaingan, Legitimasi Kekuasaan, dan Marketing Politik. Jakarta: Yayasan Pustaka Obor Indonesia.

Guo, J. \& Liu, C.H. (2012). The Perspective of Relationship: Election Strategies and Sources of Political Capital. Management Decision, 50, 8, 13401360

Hidayat, M.H. (2016). Strategi Politik Pemenangan Pasangan Kandidat Vonnie Anneke Penambunan-Joppi Lengkong dalam Pemilukada Kabupaten Minahasa Utara Tahun 2015 . Jurnal Politico, 3, 1, $1-6$.

Haboddin, M. (2017). Memahami Kekuasaan Politik. Malang: UB Press.

Kemitraan. (2011). Kajian tentang Kandidasi Perempuan di Jawa Timur dan Sulawesi Utara. Jakarta: Kemitraan.

KPU. (2017). Pilkada Serentak 2017. Diakses pada 30 Maret 2018, https:// pilkada2017.kpu.go.id/paslon/ tahapPenetapan/

KPU. (2017). Pilkada Serentak 2017. Diakses pada 30 Juli 2018, https://pilkada2017. kpu.go.id/dana-kampanye

Marijan, K. (2006). Demokratisasi di Daerah, Pelajaran dari Pilkada Secara Langsung. Surabaya: Pustaka Eureka.

Marijan, K. (2007). Resiko Politik, Biaya Ekonomi, Akuntabilitas Politik dan Demokrasi Lokal. In-house Discussion Komunikas Dialog Partai Politik (pp. 1-20). Jakarta: Komunitas Indonesia untuk Demokrasi. 
Miles, M.B. \& Huberman, A. (1992). Analisis Data Kualitatif. Jakarta: Universitas Indonesia.

Moleong, L. J. (2005). Metodologi Penelitian Kualitatif. Bandung: PT. Remaja Rosdakarya.

O'Regan, V. R. \& Stambough, S.J. (2016). Political Experience and the Succes of Female Gubernatorial Candidates. Social Sciences, 5, 1-12.

Pontianak.tribunnews.com. (30 Juni 2016). "Bagikan Seribu Kalender Berlambang Palu Arit, Ini Tanggapan Dewan Singkawang". Diakses pada 10 Agustus 2018,

http://pontianak.tribunnews. com/2016/06/30/bagikan-15-ribukalender-yang-berlambang-palu-aritini-tanggapan-dewan-singkawang.

Sarwono. (2008). Strategi Kampanye Pemilu Secara Langsung. Yogyakarta: Bukulalela.
Satunama.org. (2017). "Pilkada Serentak 2017: Menyambut Perempuan Kepala Daerah". Diakses pada 30 Juli 2018, http://satunama.org/3703/ pilkada-serentak-2017-menyambutperempuan-kepala-daerah/.

Tribunnews.com (7 Agustus 2106). "Survei LKPI: Ini Sosok yang Layak Pimpin Kota Singkawang". Diakses pada 10 Agustus 2018 http://www.tribunnews. com/regional/2016/08/07/survei-lkpiini-sosok-yang-layak-pimpin-kotasingkawang.

Stomberg, L. \& Szucs, S. (2006). Political Capital and How it Grows. Local Elites, Political Capital and Democratic Development: Governing Leaders in Seven European Countries (Editor: Stefan Szuch \& Lars Stomberg). Wiesbaden: Alle Rechte Vorbehalten

Yew-Foong, H. (2017). Decentralization and Chinese Indonesian Politics: The Case of Singkawang, West Kalimantan. ISEAS Perspective (19) 